\title{
Environmental education in its infancy at Lake Alaotra, Madagascar
}

\author{
Lena M. Reibelt',"I, Torsten Richter ${ }^{\prime, \text {,II }}$, Patrick O. \\ Waeber ${ }^{I I, I V}$, Sandanionja Rakotoarimanana", Jasmin \\ Mantilla-Contreras'
}

\author{
Correspondence: \\ Lena M. Reibelt \\ University of Hildesheim, Ecology and Environmental Education \\ Group, Institute of Biology and Chemistry \\ Marienburger Platz 22, 31141 Hildesheim, Germany \\ E-mail: reibelt@uni-hildesheim.de
}

\begin{abstract}
Madagascar is renowned for its unique biodiversity but also for the continuous degradation of its natural environment and its high poverty rate. In order to achieve sustainable development, environmental education has been assigned a key role. In the lake Alaotra region, Madagascar's most important rice and inland fish production area, primary schools are the sole formal education for the majority of the population. In order to gain an overview on the education of 'tomorrow's' resource users, this study assessed the general state of the school system and of environmental education in particular. The focus was on understanding local definitions of environmental education, its application and local perceptions of environmental problems. Over 50 in-depth interviews were conducted using the Funnel approach with teachers from 18 public primary schools. The interviews were supplemented with focus groups and a participatory problem analysis workshop. Teachers in the Alaotra region provided a different definition of environmental education than the United Nations. Their focus is on social aspects rather than the actual problems of the natural environment, which represents a different point of view than non-governmental organizations (NGOs) from abroad, who are the main promoters of environmental education in the area. This indicates that education for sustainable development might be more suitable in the region than the currently promoted environmental education. When developing educational programs, it is important to include the teachers in the development processes to ensure inclusion of local views and needs. This will increase the probability that such programs are locally meaningful and useful.
\end{abstract}

\section{RÉSUMÉ}

Si Madagascar est réputée pour sa biodiversité unique, elle l'est aussi pour la dégradation de son environnement naturel et son taux de pauvreté élevé. L'éducation à l'environnement est un élément important dans l'accès au développement durable. Dans la région Alaotra qui est le principal producteur de riz et de poissons d'eau douce de Madagascar, l'éducation est dispensée presqu'exclusivement par les écoles primaires pour la majorité de la population limitrophe du lac Alaotra. Pour comprendre globalement l'éducation des futurs utilisateurs des ressources, l'étude a évalué la situation qui prévaut dans le système scolaire en général et celui de l'éducation environnementale en particulier. Les travaux se sont concentrés sur les définitions locales de l'éducation environnementale, sa mise en œuvre et les perceptions locales des problèmes environnementaux. Plus de 50 interviews détaillées ont été réalisées avec des enseignants de 18 écoles primaires sous méthode Funnel. Les interviews ont été complétées par des groupes de discussion et un atelier participatif portant sur I'analyse du problème. Les enseignants de la région de l'Alaotra ont énoncé une définition différente de l'éducation environnementale que celle proposée par les Nations Unies. Leur priorité porte davantage sur les aspects sociaux que sur les problèmes de l'environnement naturel luimême, divergeant ainsi du point de vue des organisations non gouvernementales (ONG) étrangères, qui sont actuellement les principaux promoteurs de l'éducation environnementale dans la région. II apparait ainsi que l'éducation portant sur le développement durable pourrait être plus appropriée que l'éducation environnementale. Lors de l'élaboration des programmes éducatifs, il est donc important d'inclure des enseignants pour veiller à ce que les visions et besoins locaux soient considérés, ce qui donnera plus de chances aux dits programmes de prendre du sens et de servir leur dessein.

\section{INTRODUCTION}

ENVIRONMENTAL EDUCATION. Environmental education became globally recognized some 40 years ago (Palmer 2003) and today comprises all efforts that help individuals or societies to develop the necessary skills to enable informed decisions and actions to improve the environment. The objectives of environmental education were defined and refined during the international environmental workshop in Belgrade, Yugoslavia (Belgrade Charter 1975, UNESCO 1976) and the first international inter-governmental conference on environmental 


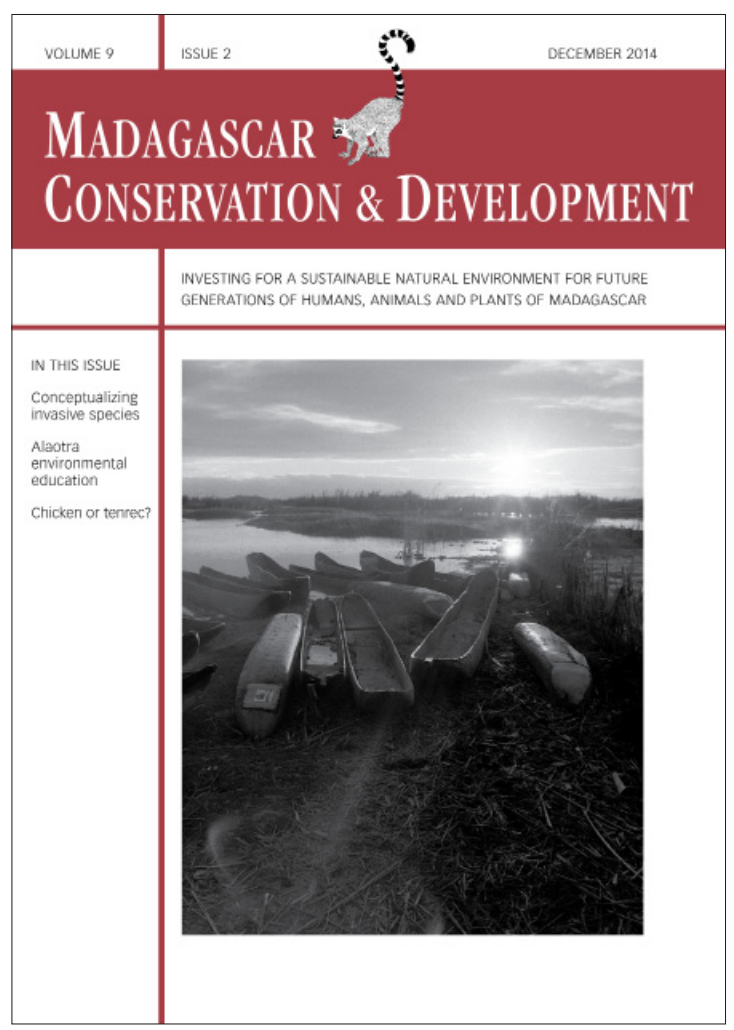

Madagascar Conservation \& Development is the journal of Indian Ocean e-Ink. It is produced under the responsibility of this institution. The views expressed in contributions to MCD are solely those of the authors and not those of the journal editors or the publisher.

All the Issues and articles are freely available at http://www.journalmcd.com

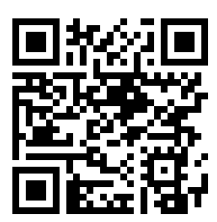

Contact Journal MCD

info@journalmcd.net for general inquiries regarding MCD funding@journalmcd.net to support the journal

Madagascar Conservation \& Development Institute and Museum of Anthropology University of Zurich

Winterthurerstrasse 190

$\mathrm{CH}-8057$ Zurich

Switzerland

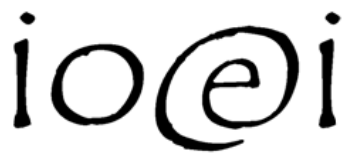

Indian Ocean e-Ink

Promoting African Publishing and Education

www.ioeink.com

Missouri Botanical Garden (MBG)

니는 Missouri Botanical Garden Madagascar Research and Conservation Program BP 3391

Antananarivo, 101, Madagascar 
education in Tbilisi, Georgia (Tbilisi Declaration 1977, UNESCO 1978). The objectives of environmental education are to help groups and individuals to develop (i) 'awareness' towards the environment and environmental problems, (ii) 'knowledge' and a basic understanding of the environment, its ecosystem functions and services, and linked problems, (iii) positive 'attitudes' and concern for the environment and the motivation for active participation of individuals and societies in environmental improvement and protection, (iv) 'skills' for identifying and solving environmental problems, and ( $v$ ) 'participation', i.e., being actively involved in solving environmental problems (UNESCO 1976, UNESCO 1978).

Agenda 21 (the global action plan towards sustainable development adopted at the UN Conference on Environment and Development held in Rio de Janeiro, Brazil, in 1992) points out the crucial role of education for reaching sustainable development, declaring it to be "critical for achieving environmental and ethical awareness, values and attitudes, skills and behavior" (UNCED 1992: 320). People educated in this way will be capable to understand environmental and development issues and to act accordingly, thus allowing public participation in decisionmaking and ensuring sustainable development in the long-run (ibid). The UNESCO states that "educators are one of the most important levers to realize educational change and to facilitate learning for sustainable development" (UNESCO 2013: 2).

ENVIRONMENTAL EDUCATION AND SUSTAINABLE DEVELOPMENT. The concept of sustainable development was first recognized in the World Conservation Strategy (IUCN 1980), and reached fame with the Brundtland Report "Our common future" seven years later where sustainable development was defined as "meeting the needs of the present without compromising the ability of future generations to meet their needs" (WCED 1987: 43). The Report applied a global view on the links between environmental and socio-economic issues, as well as future well-being for humanity, considering an economic, social and political perspective. It expressed human's dependency on the environment as well as local, regional, national and global linkage and interdependency of ecology and economy (WCED 1987: 5). Education has been assigned a key role in achieving the global aim of sustainable development (IUCN 1980). The fourth international conference on environmental education, Tbilisiplus30 dealt with the arising question how to bridge the gap between environmental education and education for sustainable development and set a global agenda for the 'UN Decade of Education for Sustainable Development' for the period 2005 to 2014 (Combes 2005, Liimatainen 2013) in order to establish an essential contribution to human development.

While environmental education focusses on the amelioration of the environment with no close link to development, education for sustainable development is concerned about the human beings, linking environmental and developmental issues (Pavlova 2011). According to Agenda 21, "Education, including formal education, public awareness and training should be recognized as a process by which human beings and societies can reach their fullest potential. Education is critical for promoting sustainable development and improving the capacity of the people to address environment and development issues" (UNCED 1992: 320). There is, however, a discrepancy in the interpretation of the two paradigms of environmental education and education for sustainable development (McKeown and Hopkins
2003); some countries use these concepts interchangeably, while others see the first as part of the second, or vice versa (Pavlova 2011).

The UNESCO proposal for the Global Action Programme (follow-up for the 'UN Decade of Education for Sustainable Development' after 2014) applies the term 'education for sustainable development' for all activities that will promote such evolution, "(...) irrespective of whether they themselves use the term ESD or - depending on their history, cultural context or specific priority areas - environmental education, sustainability education, global education, development education, or other" (UNESCO 2013: 2).

THE MADAGASCAR CONTEXT. A growing challenge in many developing countries is the reconciliation of a continuously increasing demand for agricultural products while conserving biodiversity, maintaining ecological functions and providing critical ecosystem services to sustain local livelihoods (Harvey et al. 2008, Brussaard et al. 2010). Madagascar, despite having received considerable international conservation and development attention in the past decades (Horning 2008), is still one of the poorest countries (UNDP 2013) while facing continuous degradation of its natural environment and an ongoing loss of its unique biodiversity.

The Human Development Index (HDI), calculated by the United Nations Development Programme (UNDP), is an alternative measure to the better known Gross Domestic Product (GDP) to assess a country's development state, which is measured by achievements in the dimensions of life expectancy, education, and available resources for living. Education is especially important as a stepping stone towards improved health; according to the UNDP, "a mother's education is more important to her child's survival than is household income or wealth" (UNDP 2013: 89). Madagascar with a HDI of 0.483 ranks 151 out of 187, figuring in the 'low human development group' together with many other African countries (UNDP 2013). It has globally one of the highest population growths rates (3\%) and one of the lowest median ages of 18.2. This is paralleled by an extremely high primary school dropout rate of $65.4 \%$ (in comparison, total sub-Saharan Africa is at $37.8 \%$, countries from the 'very high human development' group oscillate around $3.8 \%$ ) leaving the majority of Madagascar's population without any secondary or tertiary education. Mean years of schooling in Madagascar are at 5.2, opposed to 11.5 in countries with high HDI, but still better than in Sub-Saharan Africa with 4.7 (ibid).

Madagascar is at great risk of increasing vulnerability and degradation due to overexploitation and climate change (Hannah et al. 2008, Shepherd et al. 2013); the 2030s-projections of vulnerability to climatic extremes and disasters even put Madagascar into the globally highest risk group due to its increasing poverty (Shepherd et al. 2013). Education is crucial to acquire further competences needed to deal with threats in the future (Muttarak and Lutz 2014). This begs the question whether the current school system is capable to shoulder this responsibility?

EDUCATION IN MADAGASCAR. Madagascar had one of the

first Sub-Saharan African school systems during the Merina Kings and Queens period with formal schools mainly in the central highlands around Antananarivo, targeting the noble classes (andraina) only (Antal and Ndrianjafy 2013). With the French colonialists the formal school system started to reach 


\begin{tabular}{|c|c|c|}
\hline & Acronym & Meaning \\
\hline \multirow{8}{*}{ 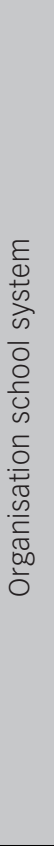 } & CISCO & $\begin{array}{l}\text { Circonscription Scolaire; regional school authorities, responsible for amelioration of results and delivery of } \\
\text { the school curriculum }\end{array}$ \\
\hline & DREN & $\begin{array}{l}\text { Direction Régionale de I'Education Nationale; Regional authority for education that governs several CISCOs, } \\
\text { i.e. representing the link between ministry and CISCOs }\end{array}$ \\
\hline & ENF & $\begin{array}{l}\text { Enseignants FRAM; community recruited teachers that are paid by the FRAM. ENF subventionnées obtain } \\
\text { additional salary by the ministry in contrast to ENF non-subventionnées }\end{array}$ \\
\hline & EP & Ecole privée; Primary private schools \\
\hline & EPP & Ecole primaire publique; Primary public schools \\
\hline & FRAM & $\begin{array}{l}\text { In Malagasy Fikambanan'ny Ray Amandrenin'ny Mpantra. Association of pupils' parents; the FRAM pay e.g. } \\
\text { (part of) the salaries of the ENF, but also necessary school material and reparations }\end{array}$ \\
\hline & T1 to T7 & First to seventh grade (in Malagasy $\mathrm{T}=$ taona; year) \\
\hline & ZAP & $\begin{array}{l}\text { Zone administrative et pédagogique; local administrative districts. The Chefs ZAP are the links between CISCO } \\
\text { and schools and in charge of teacher trainings }\end{array}$ \\
\hline \multirow{5}{*}{ 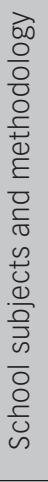 } & SVT & Science de la Vie et de la Terre; school subject 'Earth and life science' \\
\hline & FFMOM & $\begin{array}{l}\text { In Malagasy Fanabeazana sy Famolavolana Maha-Olomendrika; Education civique; School subject 'Social } \\
\text { studies' }\end{array}$ \\
\hline & APS & Approche par la situation; teaching approach \\
\hline & APC & Approche par la compétence; teaching approach \\
\hline & MITAFA & $\begin{array}{l}\text { In Malagasy Miaramamolavola ny Tanana ho Fahalalana. A hands-on teaching approach to obtain knowledge; } \\
\text { introduced by the NGO DEFI to transmit scientific topics via experiments }\end{array}$ \\
\hline \multirow{8}{*}{ 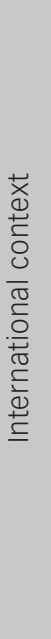 } & GDP & Gross Domestic Product \\
\hline & HDI & Human Development Index \\
\hline & UN & United Nations \\
\hline & UNCED & United Nations Conference on Environment and Development (Rio de Janeiro, 1992) \\
\hline & UNDP & United Nations Development Programme \\
\hline & UNEP & United Nations Environment Programme \\
\hline & UNESCO & United Nations Educational, Scientific and Cultural Organization \\
\hline & WCED & World Commission on Environment and Development \\
\hline \multirow{5}{*}{$\begin{array}{l}\frac{1}{\Phi} \\
\stackrel{5}{0}\end{array}$} & ARDI & $\begin{array}{l}\text { Participative problem analysis approach. In a workshop, all actors, resources, dynamics, and interactions } \\
\text { linked with a defined problem are identified }\end{array}$ \\
\hline & ENS & Ecole Normale Supérieure. Teacher training school in Antananarivo \\
\hline & INSTAT & $\begin{array}{l}\text { Institut National de la Statistique; governmental entity for production and collection of official information } \\
\text { and statistics on Madagascar }\end{array}$ \\
\hline & MWC & NGO 'Madagascar Wildlife Conservation' \\
\hline & NGO & Non-governmental organization \\
\hline
\end{tabular}


more remote areas in Madagascar. The education system in Madagascar was modeled based on the French system: maternelle, collège, and lycée with the baccalauréat exam at the end, and option to continue at university level (Sharp 2002). The Malagasy school system continued to mimic the French one also after Madagascar's independence (1960) and lasted until 1972, marking the end of the First Republic under President Philibert Tsiranana (Randrianja and Ellis 2009).

The period of 'rebelling' began in 1972 when a nationalist movement demanded the end of 'neo-colonialism', leading to the fall of the Tsiranana regime and the creation of a transitional government responsible for the introduction of the malgachisation of teaching (ibid). A socialist revolution led to the Second Republic under President Didier Ratsiraka, who adopted and furthered the malgachisation beyond the education system (Johnson 2006). Ratsiraka introduced the official Malagasy language, which was based on the Merina dialect from the central highlands. As a consequence, many non-Merina teachers speaking different dialects, and who had received all of their previous education and training in French, struggled to suddenly use exclusively the new official language (Sharp 2002). The promotion and propagation of new schools by the socialist regime led to a lack of well trained teachers, but also a lack of financial resources impeded the new government to target the country's 11,000 fokontany, especially in more rural areas. Parents often had to collect money to contribute or pay the salaries of the teachers or to provide teaching equipment such as textbooks or furniture (Johnson 2006). The lack of Malagasy teaching textbooks forced many teachers to translate the French textbooks into Malagasy. Consequently, little Malagasy culture was actually taught in schools (Sharp 2002).

With the installment of the Third Republic in 1992 under President Albert Zafy, many policies were reversed again, and French was reinstalled to assure quality in teaching and education. According to Johnson (2006), however, the problem was now a lack of teachers being able to speak and teach in French, since many teachers serving under the First Republic had in the meantime been retired. Another recurring problem was the lack of French written textbooks. The Forth Republic of President Marc Ravalomanana was a period of 'policy borrowing' (cf. Johnson 2006) to improve the school system by looking at other countries' systems. English as third official language was also introduced as third school language in primary schools. Ravalomanana invested in the building of thousands of new primary schools, and delivering also free basic material to students. During the years 1997-2007, the number of school inscriptions at primary level went up from $82 \%$ to $100 \%$; while during 2000-2006, the number of repeaters went down from $30 \%$ to $18 \%$ (MENRS 2008). According to Randrianja (2012), these improvements were due to efforts of parents associations or FRAM supporting teachers' salaries, therefore contributing significantly to the increase of number of teachers (especially ENFs). The political crisis (2009-2013) resulted in many parents struggling to survive and not being able to support the ENFs (ibid). To date, Madagascar, as many developing countries, has a "dual-track system, with the well-off attending good schools and universities, mostly privately funded, and the poor attending inadequate, mostly publicly funded facilities" (UNDP 2013: 31, cf. Glick and Sahn 2006).

THE ALAOTRA CONTEXT. The primary economic driver in the Alaotra region is based on fisheries and rice production (Andrianandrasana et al. 2005, Monographie Régionale 2012). The human population of Amparafaravola and Ambatondrazaka, the two lake districts of the Alaotra-Mangoro region, has increased from some 110,000 people in the 1960 s to over 550,000 in 2011 (INSTAT 2012). A majority of people are rice cultivators, fishermen, vegetable farmers or cattle breeders, or occupy different professions at the same time to support their livelihoods (Rakotoarisoa et al. In press).

High population growth and changes in the ecological state of Lake Alaotra are linked with declining ecosystem services (Pidgeon 1996, Lammers et al. In press). The remaining wetland system is exposed to increasing pressures, and overexploitation causes decreasing productivity (e.g., Raharijaona and Randrianarison 1999) potentially leading to a lose-lose scenario, i.e., a downward spiral of poverty and environmental degradation as described by Sunderlin et al. (2005). To counteract this resource dependency and depletion, non-governmental organizations (NGOS) such as Durrell Wildlife Conservation Trust (Durrell) have been working in the region for more than 20 years. A case study done by Durrell has shown a positive correlation between education and environmental awareness (Andrianandrasana et al. 2005). The Madagascar Wildlife Conservation (MWC) found increased knowledge for environmental issues in school children after participation in the environmental education program (Dolins et al. 2010, Rendigs et al. In press). MWC has been running this program since 2006 and developed culturally and regionally adapted posters and comic books for the region to be used in public primary schools by trained teachers (Maminirina et al. 2006).

The goal of this study is to assess the state of environmental education in the Alaotra primary public schools. It is assumed that significant numbers of future resource users can be reached if environmental education is implemented on primary school level. Environmental education can strengthen conservation efforts such as maintaining ecosystem functions and biodiversity by contributing to improved awareness of and appreciation for the natural environment. Assessing the current situation is the first step in developing suitable and regionally adapted environmental education programs. Such education is hypothesized to advance sustainable development. This paper has two main objectives: (i) to understand the perceptions of 'environment' and 'environmental education' at primary schools at the teacher level, and (ii) to describe the school structure in terms of readiness for environmental education.

\section{METHODOLOGY}

A total of 18 primary schools around Lake Alaotra were selected based on the following criteria: (i) Public primary school; (ii) adjacency to the lake and remaining marshes; and (iii) accessibility, i.e., vicinity to Routes Nationales 3 and 44 (east and west coast of the lake, respectively).

Structured one-on-one interviews with 54 teachers (including 18 school directors) were conducted. Half of the interviewees were selected based on participant lists of former MWC trainings and the other half were randomly sampled teachers without such training. A standardized interview guide according to the Funnel approach (cf. Wittkowski 1994) has been developed in order to avoid a social desirability bias (Paulhus 1991). Interviewers using the Funnel approach start with broader 
subjects and gradually narrow down their topics of interest, thereby masking the motivations of the interviewers from the interviewees. The Funnel approach is intended to reduce the tendency of interviewees to answer questions in a way they believe the researcher welcomes, instead of offering their own opinions (ibid). All interviews were audiotaped, transcribed and translated from Malagasy into French. Average interviews were 60 to 90 minutes. Prior informed consent was obtained regarding audiotaping ensuring the teachers' anonymity. It was emphasized that there were no right or wrong answers but a range of different personal opinions. A pilot interview guide was tested with the interviewer, a Malagasy anthropologist, to ensure methodological adequacy and cultural sensitivity, profiting from his experience during former surveys in the region. The interview guide addressed four major topics with multiple sub-questions (cf. Supplementary Material for details): (i) general situation in the village, e.g., social environment; (ii) school environment; (iii) natural environment; (iv) teacher trainings. Major topics included structural conditions of the schools such as availability of material and trainings, environmental situation and problems in the region, as well as environmental education and possibilities of its implementation. After each interview, participants completed a short questionnaire, indicating biographic information and details on their personal education and career.

To allow for triangulation of results, the structured interviews were complemented by further applying a participatory problem analysis workshop, ARDI (Actors, Resources, Dynamics, Interactions; Etienne et al. 2011), focus groups, participant observations and archival research. ARDI is a methodology deployed to collectively analyze a problem. During this two-day workshop, 12 teachers (randomly selected from the 54 interviewees) addressed the problem that there is not enough material for (environmental) education, and determined involved actors, existing and needed resources, dynamics in the system, as well as interactions between its components. Additionally, 6 focus groups totaling 50 participants were conducted. The majority of the teachers were the same as for the interviews (with few replacements). These meetings followed a similar structure as the interviews, but permitted further discussion in greater detail of teaching approaches and other issues. The interviews had revealed some gaps that could be filled with the results from the workshop and meetings. Additional data to complement and verify the interviews was obtained from the group approaches.

Data analysis was supported by the commercially available software program MaXQDA 11 which uses data management techniques such as multiple levels of coding, memo creation and code segment search. Coding is the method by which text is classified, analyzed, and grouped into categories. These were developed, tested and adapted while considering objective, research questions, methodological approaches and resources.

\section{RESULTS}

PRIMARY SCHOOL SYSTEM. The two Alaotra CISCOS (Circonscription Scolaires) with 43 Chef ZAP (Zone Administrative et Pédagogique, the administrative districts) currently oversee a total of 702 primary schools; 540 EPPS (Ecole Primaire Publique, public schools) and 162 EPs (Ecole Privée, private schools). Over 3,300 teachers are responsible for the education of nearly 116,000 pupils between 7 and 15 years old (Maminirina et al. 2006, CISCO 2013). The CISCO Ambatondrazaka teaches students from first to fifth grade while pupils under the authority of CISCO Amparafaravola are supposed to attend primary school until seventh grade (T7). However, T6 ( $6^{\text {th }}$ grade) and T7 are realized in 61 out of 343 schools only ( 57 public and 4 private schools) resulting in $17.8 \%$ of the schools implementing this new model of having seven grades in primary school since 2009.

There are three employment types at EPPs: i) Fonctionnaires: $930(37 \%)$ of the present teachers were recruited and are paid directly by the Ministry of National Education; ii) ENFS: 969 (38\%) are community recruited teachers; the ENF subventionnés (ENseignant FRAM) are paid half by the Ministry of National Education, and by the pupils' parents, respectively; iii) ENF non-subventionnés: 643 (25\%) have to be financed by the parents alone.

The 18 sampled schools have an average class size of 49 pupils with a minimum of 18 and a maximum of 92 children per class. School sizes ranged from 5 to 23 classes with 4 to 24 teachers, respectively. Of the 54 interviewees, $74 \%$ were women and $26 \%$ men, reflecting the fact that the majority of the Alaotra EPPs' teachers are women. The retirement age for teachers is at 60 years. The sample size shows that more than half of the teachers are close to retirement (53\%). Almost all teachers have attended secondary school, but only $9 \%$ hold a university degree. Out of the 54 teachers, $65 \%$ are Fonctionnaires, $17 \%$ are ENF subventionnés, and $18 \%$ are ENF nonsubventionnés.

The CISCO's responsibility is to implement the school program that the Ministry of National Education delivers via the DREN (Direction Régionale de l'Éducation Nationale, regional authority for education). The main objective is a continual amelioration of results, i.e., the increase of successful exams passed by the school children. The Chefs ZAP assist the CISCO in the delivery of the school curriculum's content by organizing training sessions to transmit instructions and methodological modifications to the directors and teachers of the EPPS.

According to the teachers, teaching subjects are received in irregular intervals (e.g., the CISCO organized trainings every trimester or every three months). Each month there is a Journée Pédagogique (one day teacher training) and once a week a Conseil de Maîtres (teacher's meeting) during which the teachers have the opportunity to exchange with their school directors and amongst peers. The Chef ZAP as instructor can be supported by the CISCO's Equipe Pédagogique as there are the Adjoint Pédagogique, the Conseillers Pédagogiques and the Chef CISCO. The CISCO is also responsible for the follow-up and monitoring of the teachers. These suivis are mainly conducted by the Chefs ZAP and serve as control measures to ensure the curriculum-relevant topics have been transmitted properly during the CISCO trainings, but also to assess the teachers' ability to implement the provided subject contents.

SCHOOL CURRICULUM AND TEACHING METHODS.

One school year in Madagascar lasts nine months, i.e., from October to July. Generally, there is one teacher for each class, teaching all school subjects in the respective level (T1-T5/T7). A lesson takes 30 minutes while the teaching approach consists of consecutive stages which must be completed in order. The revision of the previous lesson is followed by an introduction and préacquis, i.e., children will recall what they know already about a certain topic. The next steps are giving the title of the 
lesson, teacher presentation of the new lesson, application and group work, and finally ending with an evaluation (report and identification of results as well as rectification).

To execute their lessons, several approaches are available as teachers stated in the ARDI workshop: banking education (sensu Freire 1970, Dewey 2004) where the teacher presents the content to the pupils without discussion or any other interaction; the active and participatory method that are the most efficient ones for teaching, allowing pupils for example to manipulate material during experiments; different strategies such as group work and individual work, encouraging the pupils to play games or using little songs and rhymes to transmit the lesson's content. These methods and strategies are supplemented by approaches (démarches) and procedures (procédés) from the Ministry of National Education and NGOs. According to the teachers interviewed, the teaching methodologies are changing frequently with the mandatory application of new approaches promoted by the CISCO: APC (Approche Par la Compétence), APS (Approche Par la Situation), MITAFA (MIara-mamolavola ny TAnana ho FAhalalàna, doing experiments with the pupils to understand science; introduced by DEFl, a French NGO). There is a trend to move away from the banking education towards more group and participatory work which is for example encouraged in the APC context. In order to comply with the new directives despite a shortage of material, the teachers oftentimes are forced to develop teaching material on their own. However, since teachers are required to follow the school program, there is often insufficient time available for implementation of these non-traditional methods (e.g., going to the market to introduce mathematical problems in an interesting way).

The main school subjects are mathematics, Malagasy, earth and life science (SVT: Science de la Vie et de la Terre), geography, French, social studies (TSM which includes FFMOM/ éducation civique and history); complemented by music, art, sports, recitation (i.e., repeating something aloud from memory, e.g., recitation of traditional poems) and reading. The teacher's ranking of these school subjects revealed no common agreement on their practical importance for students later in life. There is, however, a trend showing reading to be the most important skill for adult life, followed by Malagasy, writing and mathematics; the nonschool subject household is ranked on second place while environmental education figures comparatively low (Figure 1).

TEACHER'S UNDERSTANDING OF ENVIRONMENTAL

EDUCATION. Teachers' understanding of education in general is described mainly as "transmission of knowledge". Several teachers added that education is "learning on the intellectual, physical, and spiritual level" while others described it as learning how to act as a "good citizen", i.e. showing a "good behavior in society". To better understand what exactly environmental education means to the local teachers, we asked this question in the face-to-face interviews, as well as in the ARDI workshop and focus groups. During these group meetings, the following definition of environmental education has been compiled: it is the "transmission of knowledge about the environment", thus "learning about everything that belongs to the environment, about existing environmental problems and their possible solutions", and about the "protection of the environment". The teachers stated that it is important to know who the actors are (who have destructive impact on the environment) to be able to "become a responsible citizen". While teaching envi-

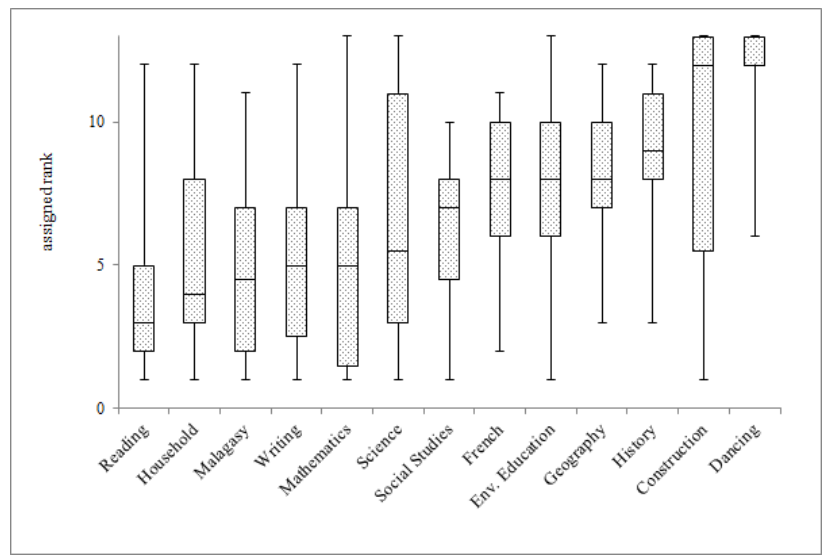

FIGURE 1. Ranking school subjects. Teachers $(n=51)$ ranked 13 cards with school subjects (e.g., Malagasy, geography, history) and non-school subjects (e.g., housekeeping, dancing, environmental education) according to importance for after school life. The box-whisker plots show median, upper and lower quartiles, and minimum and maximum rank of the respective school subjects.

ronmental education, knowledge on "everything that surrounds us", "the whole that is visible and invisible" is been transmitted. According to them, both, natural environment (e.g., water, forest, including humans) and anthropogenic environment (e.g., houses, roads) are addressed.

During the one-on-one interviews, simpler definitions of environmental education were listed compared to the group meetings, mainly encompassing what the environment entails and defining environmental education as "transmission of knowledge about these components". Some teachers however also included the conservation aspect: environmental education is "teaching the pupils about the components of the environment and its importance. How can it be conserved? Who is responsible for its destruction? What are the consequences of this destruction?" Another interviewee stated that "environmental education is teaching people what the environment constitutes, its state or condition and finally its conservation".

Teachers state that environmental education is already taught in the current school system even if no specific school subject exists for this. In their opinion, best suitable for the integration of the environmental topics are the school subjects SVT (Science de la Vie et de la Terre), FFMOM and geography, but also Malagasy, French, history and even mathematics offer such possibility to some degree.

Building on this background, teachers' opinions on the importance of environmental education compared to school and other non-school subjects varied: though environmental education ranked amongst the least important topics on average (Figure 1), personal opinions were quite diverse. Sixteen percent declared environmental education to be the most important topic, $12 \%$ ranked it on 2 nd, $18 \%$ on 3 rd and $4 \%$ on 4 th and $12 \%$ on 5 th rank. The remaining $40 \%$ were distributed on ranks 6 to 11 . None of the interviewees ranked it the least important topic for a primary school. In terms of a possible implementation of environmental education, $100 \%$ of the interviewees said that it already is included in the current curriculum, i.e., environmental education appears in many of the topics they are teaching while several book chapters are dealing with the environment. Geography deals with environmental destruction by addressing bush fires and tavy (slash and burn agriculture). FFMOM (Fanabeazana sy Famolavolana Maha-Olomendrika, i.e., education 
with the aim to make the children become an adult person with good manners) also deals with 'the environment' where they introduce environmental education by addressing "all questions concerning the health as for example personal hygiene". When they present possible consequences of using river water, "the environment is already introduced". This example suggests that some teachers believe environmental education is sufficiently taught as soon as the natural or social environment is barely mentioned. Teachers state that other book chapters are explaining 'What is the environment?' or treat the topic 'How to avoid erosion' or 'The protection of the environment', herein focusing on the protection of plants and animals.

The teachers are aware of many kinds of environmental problems in and around their villages. These can be grouped into the three categories 'ecosystem', 'humans', and 'agriculture' (Figure 2). The ecosystem perspective entails destructive human practices and their consequences on the natural environment. The social or human perspective mainly focusses on problems in the village that are related to the low development state, and the agricultural perspective comprises causes of management strategies and climate conditions that have negative impacts on the agricultural output. When describing problems of the natural environment, the teachers oftentimes just briefly mention the environmental issue and then focus on the social impact resulting from it.

When answering the question about regional environmental problems, one third of the interviewees mentioned poverty as a cause for environmental destruction and one fifth tried to explain people's behavior with their mentality or mindset, in particular referring to people's laziness and jealousy: "They know that they shouldn't burn the marshland, but when they see the advantages and benefits of the persons who protect the environment here, they ask themselves why this benefit is not shared but reserved to and kept by one person. So they quarrel and in periods like now [political instable times with no working executive powers / dry season] they continue to burn the marshland". speaking about mentality, one third of respondents complained that people do not plant trees or do reforestation but also address the problem that "someone burns them [the planted trees] all the time". Teachers declared fire to be the most

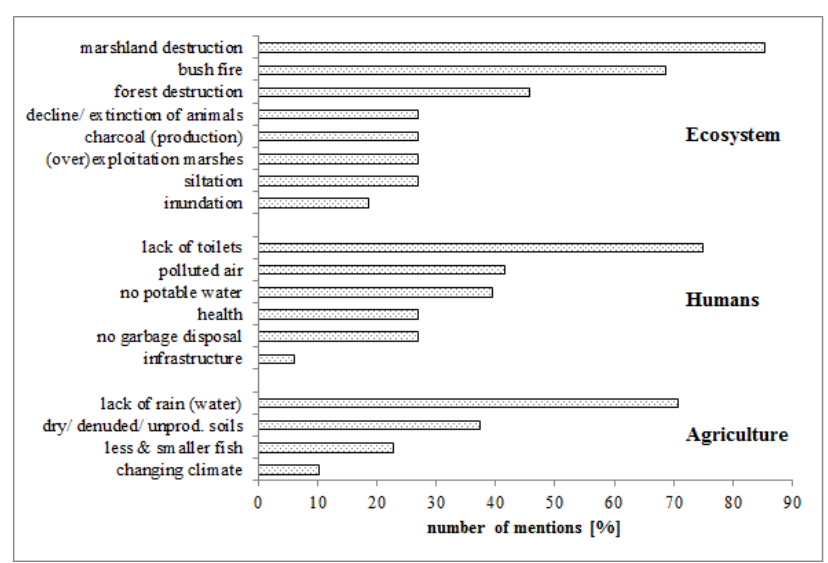

FIGURE 2. Listing regional environmental problems. The teachers specified environmental problems as perceived by them ("Please describe the environmental situation in your community. Are there environmental problems? Which environmental problems do exist?"). The various answers were grouped into the three main categories 'ecosystem', 'humans', and 'agriculture' (problems that affect directly the agricultural production) with the above listed sub-categories. $X$-axis is the percentage of interviewees $(n=48)$ who mentioned the respective issue listed on $y$-axis. threatening problem for an intact environment when showing them ten different photographs with potential environmental problems being present at the lake to date. These photos were chosen according to what had been encountered during the first few weeks on the ground, either by sight or by reports from residents. Almost all interviewees also identified charcoal and erosion to be important environmental pressures (98 and $96 \%$, respectively), as well as crayfish ( $92 \%$ ). Inundation was judged a potential environmental problem by $77 \%$ of the interviewees, while the invasive fish species snakehead and pesticides were identified by $58 \%$ and $40 \%$, respectively. Only $25 \%$ declared (marsh-penetrating) zebu to be potentially problematic; $6 \%$ listed the invasive plant water hyacinth; rice fields were not listed by any of the teachers (cf. Supplementary Material).

\section{DISCUSSION}

LANGUAGE BARRIER. Since many of the Alaotra teachers are not confident with French or speak only little to conduct extensive discussions, all data sampling had to be done in Malagasy. Interestingly, many of these teachers are from the generation of the malgachisation and hence did not have the opportunity to learn French. To reduce the risk of missing out on details, i.e., getting lost in translation, different approaches for data sampling were used allowing for triangulation of the results. Additionally, random translations have been cross-checked by the interviewer to ensure quality. Though even with a seemingly small data set ( $n=54$ out of over 3,300 teachers of public primary schools) we can be confident that the data set is representative, since there were many agreements in terms of responses.

Another language barrier is present in the school system itself. Today, Malagasy primary school classes are bilingual (Malagasy and French). In the first two grades, pupils are taught in Malagasy, the third grade allows theoretically a bilingual transition to 4th and 5th grade where lessons are or at least should, according to the curriculum, be held in French. The question remains, however, to what extent this is or can be realized by the teachers that were educated during the malgachisation. various publications declare the teaching language a key factor for learning (Brock-Utne 2000, Heugh 2000, Benson 2004, Abadzi 2006) and state the importance to teach in the mother tongue. Language as "basic tool for thought, communication, reasoning, and making sense of a rapidly changing world" (Arnold 2004: 3) can even serve for predicting later abilities and school success (Hart and Riseley 1995, Shonkoff and Phillips 2000). In Madagascar, however, exams are held in French from the third grade on which poses a great language barrier to learning and succeeding at school.

LACK OF TRAINED TEACHERS. In the Alaotra region, the primary public schools are facing an uncertain near future due to an increasing lack of professionally trained teachers. A significant body of aging teaching staff is currently close to retirement and teachers are complaining that since 2009 there is no more recruitment of teachers paid by the state (fonctionnaires) and thus more ENFs (community-recruited teachers) are hired for less payment. Fonctionnaires normally obtain trainings for two years at the École Normale before they are recruited by the Ministry of National Education, whereas the ENFs are selected via application by the CISCO without necessarily having such a considerable education. This could potentially contribute to a deterioration of teachers' educational levels in the region. 
Our data sample includes $65 \%$ fonctionnaires opposed to $37 \%$ in reality. This might result in a slightly different picture regarding teacher's educational levels as well as knowledge and understanding on certain topics. If few well-trained teachers are recruited, this inevitably will leave a void and the overall educational quality level in the first grades will decrease. It is well-known, however that quality teaching is especially crucial in the first grades (Bruns et al. 2003, Abadzi 2006) and that attitude and behavior are mainly developed based on experiences in childhood (e.g., Kidd and Kidd 1989, McDuff and Jacobson 2000, Jacobsen et al. 2006). Sobel (1997) admonishes not to impose ecological problems on children before a certain age to avoid the feelings of fear and disempowerment ('ecophobia'). He suggests age-appropriate environmental education contents for developing the necessary emotional connectedness that will later allow them to deal with the complex ecological issues. such age-appropriate education, however, requires accordingly trained teachers.

Ongoing political changes and irregular trainings pose on the one hand insecurity and require (methodological) adaptation by the teachers, but also give them the impression that their "expertise is questioned". On the other hand, the principle formation de formateurs (cascade training: the Chefs ZAP will train directors and teachers on the ground after having received trainings themselves) can offer an effective approach for introducing new methods and the changing requests by the Ministry of National Education keep the educators flexible and open for new teaching approaches. Since 2012 (start of the AMBio research project, Alaotra Marshland Biodiversity), the Chef CISCO in Amparafaravola and lately the Chef DREN in Ambatondrazaka have been replaced, and further changes are likely to follow. Such instability might be one reason amongst others why plans by the government to restructure and improve the school system, and even to include Malagasy biodiversity into teaching, have been on hold (Dolins et al. 2010). Even if the Malagasy curriculum addresses some environmental topics (cf. Ormsby 2008) there is a lack of site-specific content.

In the past decades, NGOs have been filling these gaps by providing educational material and proposing new teaching approaches (e.g., Waeber 2006, Maminirina et al. 2006, Dolins et al. 2010). However, the provision of material alone might not be sufficient when teachers do not know how to use the material (cf. Dolins et al. 2010) or if they lack understanding of the topic or the motivation to teach it. Developing locally adapted tools and training teachers in how to use them might increase the chance of meaningful use of such educational material in the classroom. The integration of new material should be endorsed by the CISCOs, an approach generally taken by promoters of environmental education in Madagascar (e.g., Masoala curriculum development, Ormsby 2008; MFG's Saturday School at Park Ivoloina, Nirina L. Rakotomalala, pers. comm.; MWC's educational posters and comic books). Teachers in the Alaotra region state that they are regularly using the material provided by MWC. Research by this NGO and ENS (École Normale Supérieure) has shown that the material can be integrated in school subjects such as mathematics, Malagasy, French, geography and SVT (Rafidimanana Rajosera 2013).

A MATTER OF PERSPECTIVE. Many of the NGOs acting

in Madagascar are from foreign, mostly western countries and their values and perspectives may differ from those of the
Malagasy communities. Concerns about biodiversity loss and threatened lemur species are motivating various NGOs to be active and to bring in environmental education to promote conservation. This situation can possibly cause a 'clash of values'. On the one side are the NGOs with an implicit view on education and the emphasis on environmental education, on the other side the regional traditional value systems with locally meaningful and long-time corroborated perspectives.

A value, as defined by Tilbury (1995: 201) is "a certain belief, attitude or conviction that is consistently reflected in one's behavior. Values determine decisions and actions and are thus of great consequence to environmental education". Breidlid (2009) addresses the drawback of such western-based educational systems in Africa. He criticizes the exclusion of alternative, i.e., African knowledge and value systems from the curricula of the post-colonialized countries. He further states that ignoring traditional values and leaving out the spiritual sphere (traditional beliefs, ancestors) could cause a collapse of the social and moral world and existing solidarity amongst the population might get lost.

Interestingly, in the Alaotra region none of the interviewed teachers did refer, for example, to ancestors as part of the environment despite their important role in tradition and beliefs of the Malagasy population (cf. Jarosz 1994, Keller 2009, Evers and Seagle 2012). A plausible reason for this could be that the current school curriculum is still based on the colonial French school system with many subjects addressing little or no Malagasy context. This assumption is illustrated by the following example. Many teachers mentioned 'polluted air' as environmental problem. French textbooks that are still in use (pers. observ.) are dealing for example with the negative impacts of factories on air quality and consequences for human health. There is no such air pollution in the Alaotra region, but teachers adopt this textbook content on their regional reality: "the environment is also affected because there are no toilets; people defecate everywhere and the air is thus polluted". Polluted air is also oftentimes mentioned in the context of waste dispersal and the lack of garbage disposals.

When the teachers ranked the different 'environmental problems' during the interviews, a congruency of western and regional perceptions appeared, for example regarding fire and charcoal of being main threats in the region. On the other hand, there was often hesitation or confusion whether, for example, the invasive fish species Channa maculata is representing an environmental problem (as assumed by a western perspective because it feeds on endemic fish and bird species (Andrianandrasana et al. 2005) or not. This species was chosen as representative for introduced fish species at Lake Alaotra (cf. Pidgeon 1996) that are still common today and consumed regularly. Many teachers mentioned that the fibata (vernacular name for C. maculata) eats little fish or even stated that it is the enemy of the fish stock in general. But in an environment where malnutrition and lack of protein are wide-spread, some teachers still decided not to put C. maculata as environmental problem despite knowing its ecological impacts. This fish thus represents a good example for a trade-off situation between negative environmental impacts versus an improved social situation. The question arises how committed and supportive the teachers can or will practice environmental education if their own 'Lebenswelt' (this translates as 'human-life world', 
cf. De Laguna 1960) is not reflected in the teaching material and content? Local realities need to be taken into account to increase probability of acceptance and success of environmental education programs.

Following the UN, teachers are seen as crucial in delivering the sustainability message. At first glance, the teachers' understanding on environmental education seems to be congruent with the international definitions (cf. UNESCO 1976). The teachers define it as the "transmission of all knowledge that is related to the environment (...)" with examples for environment such as forests, the air, stones, roads, and houses. In contrast, the UN concept of environmental education incorporates much more than the local perspective which represents only the first step, the knowledge transfer, of the international definition. Though knowledge is crucial in achieving higher cognitive levels such as understanding, awareness and sensitivity, attitudes and motivation, and skills for participation and action, pure knowledge transfer is clearly not sufficient as teaching objective.

According to the teachers, environmental education already appears in many of the topics they are currently teaching, and several text book chapters are dealing with the environment. However, as some of the following examples show there is a disparity of what the authors understand of environmental education and what the teachers think in this regard. For example, one teacher stated that she included environmental education by giving an arithmetic problem where the children had to calculate the benefit of 20 planted shoots of manioc. Another teacher claimed teaching about health centers to be environmental education, while another stated that discussing the benefits of trees on the hill slopes around Lake Alaotra constitutes environmental education.

During the interviews, when the Alaotra teachers listed environmental problems, the focus revolved mainly around social and health related topics ('humans'). The teachers revealed detailed descriptions and understanding of problems when they talked about social and economic misfits using oftentimes compelling examples. Fewer details were touched on when talking about the natural environment, by barely naming a problem or briefly listing a sequence of several ecosystemrelated issues, to end in many cases again with a social-centric environmental problem: "the bush fire causes soil loss and hence the canals here get clogged by the accumulation of mud which are brought by the waters and the streets get flooded", or, "even the well (...) is not very sanitary because it is not covered and when the rain is arriving, the drain water pours into the well, together with the waste from the surroundings". This emphasis on social impacts, even when ostensibly speaking about natural environments, matters locally and needs to be addressed when drafting environmental education programs. During some of the interviews, the impression occurred that the teachers were citing facts without deeper understanding of interrelationships or reasons. Many of the Alaotra teachers are from the generation of the malgachisation and have been indoctrinated with recitation teaching by the socialist regime. This causes unpredictable consequences for the next generations as these educators did not learn how to think critically but to learn by heart and to repeat slogans only.

As long as the Alaotra population suffers from deficient hygiene and health issues there will be little sympathy for ecosystem problems, and relationships between deteriorating ecosystem services and health or development might remain misunderstood. A central question remains how the different value systems of external western providers of environmental education (such as NGOs, cf. Rendigs et al. In press) and local teaching staff and communities can be married to achieve development in all environmental aspects in combination with conservation success. This is where environmental education can act as leverage, emphasizing the linkages between a healthy environment and its services, but also by serving the local needs by introducing for example concepts such as PHE (People, Health, and Environment; cf. Robson and Rakotozafy In press) for a successful model in Madagascar).

FROM TEACHER-CENTERED LEARNING TO LEARNER-

CENTERED APPROACH. As Kollmus and Agyeman (2002) state, there is no apparent, direct correlation between knowledge and pro-environmental behavior. Having in mind that action competence may be the one main goal of environmental education, Jensen (2002) adds that a clear distinction should be drawn between behavioral change and action. Behavioral change is oftentimes directed by others, while action "should be directed at solving a problem and it should be decided upon by those preparing to carry out the action" (Jensen 2002: 326), direct or indirect, individually or collectively.

How these obvious gaps between environmental knowledge and attitude change towards positive environmental actions may be bridged is still open to debate. It is well known that knowledge about and positive attitudes towards the environment are necessary prerequisites but in themselves are not strong enough to lead to action (Schultz 2011, Heberlein 2012). An environmental education program aimed at changing people's behavior should therefore steer away from teacher-centered learning (banking education). It needs a learner-centered approach that is connected to the scholar's every-day life and has a real issues orientation, and is in its nature participatory and allows the learning process to be driven by the learners. It should integrate new teaching methods like outdoor activities, participative inquiry, group activities and discussions or action learning on real-life problems. This approach targets a broad set of scholars' competencies, thereby facilitating systemic and critical thinking, reflection and future orientated thinking. This strengthens the competencies of learners for shaping their future in a positive way (consider Palmer 2003, Tilbury 2007, Cotton and Winter 2010, de Haan 2010, for an in-depth discussion on appropriate teaching methods). Furthermore, a culture-specific approach to environmental education taking into account local values and belief systems is also needed to address and ensure environmental behavior via education (Boeve-de Pauw and Van Petegem 2011).

The concept of the Gestaltungskompetenz (cf. de Haan 2006, and references therein) promotes a learning to invoke change (in for example ecological, economic or social behavior) through a combination of skills acquisition and competencies (i.e., to build on children's every-day experiences) that goes beyond the pure accumulation of 'inert-knowledge' (sensu Renkl et al., 1996). Such knowledge-based or banking education is one of the main challenges in Madagascar's school system. Not surprisingly, teachers judge the school subjects reading, Malagasy, writing, and mathematics as likely most important to be successful in after school life, being congruent with the set 
of principles the Ministry of National Education stated for their school children. When leaving the primary schools in Madagascar they are expected to master (i) academic achievements such as skills in reading and writing, arithmetic, and problem solving (e.g., Bloom's taxonomy: comprehension, application, analysis, synthesis and evaluation), (ii) social skills (attitudinal modernity, interpersonal effectiveness, community involvement), and (iii) economic success (earnings and productivity) (Heneveld and Craig 1996). The non-school subject household being ranked on second place by the Alaotra teachers correspondingly represents the social perspective.

The social environment is in teachers' perceptions higher prioritized than the natural environment. Teachers are exposed on a daily basis to social problems which are consequences of the urban environment and carried by the children into the class rooms. For example, many students come from impoverished households, are malnourished, and have poor hygiene. It has been shown that socioeconomic status globally plays a crucial role in children's development (Brooks-Gunn and Duncan 1997, Bradley and Corwyn 2002), and that such low status negatively affects behavioral and cognitive development in children (Grantham-McGregor et al. 2007). This results in poor performance which is reflected in the higher numbers of repeaters, or an increase in the drop-out rate (Arnold et al. 2007). Apart from this, it is well known that the experiences in early childhood shape the later learning processes; physical, cognitive, and emotional development of children are best supported by (various and rich) natural settings, i.e., children have to experience nature themselves to achieve a holistic learning (cf. Rivkin 1995). Following a more proactive and interactive school approach by visiting, for example, the market or the marshes could already act as a stimulant in this direction. Although being envisioned by the school authorities, the realization of the approach remains a challenge due to lack of resources, time and motivation.

Even if the structure of the school system provides opportunities to address environmental education or education for sustainable development, environmental education as defined by the United Nations (UN) is to date implemented in the Alaotra region only on a basic level. Potential drivers and barriers of such implementation remain to be identified. Further research in the next two years thus will focus on barriers that are opposed to the implementation of environmental education into the school curriculum and drivers that will facilitate such implementation in the Alaotra region. Addressing the questions on what potential drivers represent, and how they could be used to tackle potential barriers will help to develop material that is adapted to the regional circumstances and learning environment. Including sustainability issues into the curriculum can be a challenge and should aim for addressing locally relevant terms and appropriate solutions rather than frightening the audience (children as teachers alike) with global problems, which are not understandable, likely irrelevant, let alone solvable on local scale and conditions (Tilbury et al. 2002).

\section{CONCLUSIONS}

The school system in Madagascar has a hierarchic structure, and changes are commonly dictated from the Ministry of National Education or DREN and CISCO. It is thus crucial to involve the higher levels of the school system when introducing environmental education, not only the schools themselves. The DREN and CISCOs are the official government entities for the realization of teacher trainings, and are crucial partners in the delivery and implementation of such new tools.

As the primary schools are the sole formal education for a majority of rural children, teachers could act as promoter of education that will allow pupil's to face their future by furthering critical thinking. Teachers are shouldered with this responsibility. It is therefore important to overcome the banking education and to proceed towards a more participative and interactive learning, with teachers needing to be trained by the respective school authorities accordingly. Overcoming the impacts of malgachisation however, might still require some time and effort. The regional educators cannot be used only as instruments for implementation, but must be involved during the creation and development of educational tools or programs. It is assumed that this will increase teacher's creativity, motivation and initiative in their teaching process. Including teachers in the tool development process will provide them with new techniques, new approaches, and especially increase confidence to address new topics or to try out new ways themselves.

When drafting environmental education programs, the population's needs, concerns, and local value systems need to be taken into account. Consequently, a participatory approach needs to be chosen when drafting such programs. Given the anthropogenic view and emphasis on social values revealed by the interviews, the Alaotra schools and teachers might be better served with education for sustainable development rather than environmental education only. Following the principles of mutual respect, empathy and understanding will result in educational and development programs which can meet the expectations of all involved parties and are more likely to be continued even if projects or other external input such as funding are coming to an end.

\section{ACKNOWLEDGEMENTS}

The DREN, CISCOS, Chef ZAP, directors and teachers in the Alaotra region are acknowledged for supporting our research and for participating in our study. We thank Durrell and Madagascar Wildlife Conservation for their collaboration and the support on the ground. A special thanks goes to Antje Rendigs (MWC) for her continuous support, motivation, feedback and for sharing her experience in the region. Dr. Nils Benit provided valuable insights during the design of this study. Our acknowledgements are extended to the translators of the interviews and group discussions. Thanks to the Stifterverband für die deutsche Wissenschaft for financial support of the AMBio project, and to MCD's anonymous reviewers and the editors for their comments on a previous version of this manuscript.

\section{REFERENCES}

Abadzi, H. 2006. Efficient Learning for the Poor: Insights from the Frontier of Cognitive Neuroscience. The World Bank, Washington, D.C. Available at <https://openknowledge.worldbank.org/bitstream/ handle/10986/7023/366190Efficien101OFFICIALOUSEOONLY1. pdf? sequence $=1>$

Andrianandrasana, H. T., Randriamahefasoa, J., Durbin, J., Lewis, R. E. and Ratsimbazafy, J. H. 2005. Participatory ecological monitoring of the Alaotra wetlands in Madagascar. Biodiversity \& Conservation 14: 2757-2774. (doi:10.1007/s10531-005-8413-y) 
Antal, C. and Ndrianjafy R. K. 2013. Madagascar. From political divisionism to unified development. In: Education in Southern Africa. C. Harber (ed.), pp 81-102. Bloomsbury Academic, London and New York.

Arnold, C. 2004. Positioning ECCD in the 21st century. Coordinators Notebook 28: 1-36. Available at <http://www.crin.org/docs/resources/ treaties/crc.37/Caroline_Arnold.pdf>

Arnold, C., Bartlett, K., Gowani, S. and Merali, R. 2007. Is Everybody Ready? Readiness, Transition and Continuity: Reflections and Moving Forward Working Paper 41. Bernard van Leer Foundation, The Hague, The Netherlands.

Benson, C. 2004. The importance of mother tongue-based schooling for educational quality. Background paper prepared for the Education for All Global Monitoring Report 2005: The Quality Imperative. UNESCO. Available at <http://unesdoc.unesco.org/ images/0014/001466/146632e.pdf>

Boeve-de Pauw, J. and Van Petegem, P. 2011. A cross-cultural study of environmental values and their effect on the environmental behavior of children. Environment \& Behavior 45, 5: 551-583. (doi:10.1177/0013916511429819)

Bradley, R. H. and Corwyn, R. F. 2002. Socioeconomic status and child development. Annual Review of Psychology 53: 371-399. (doi:10.1146/ annurev.psych.53.100901.135233)

Breidlid, A. 2009. Culture, indigenous knowledge systems and sustainable development: A critical view of education in an African context. International Journal of Educational Development 29, 2: 140-148. (doi:10.1016/j.ijedudev.2008.09.009)

Brooks-Gunn, J. and Duncan, G. J. 1997. The effects of poverty on children. The Future of Children 7, 2: 55-71.

Bruns, B., Mingat, A. and Rakotomalala, R. 2003. Achieving Universal Primary Education by 2015: A Chance for Every Child. Report no. 26605. World Bank, Washington, D.C. Available at <http://siteresources.worldbank. org/EDUCATION/Resources/278200-1089739404514/ achieving_efa_ full.pdf>

Brussaard, L., Caron, P. Campbell, B., Lipper, L., Mainka, S., et al. 2010. Reconciling biodiversity conservation and food security: scientific challenges for a new agriculture. Current Opinion in Environmental Sustainability 2, 1-2: 34-42. (doi:10.1016/j.cosust.2010.03.007)

Brock-Utne, B. 2000. Whose Education for All? The Recolonization of the African Mind. Falmer Press, New York and London.

CISCO 2013. Statistique de I'Enseignement par ZAP, Circonscription scolaire Amparafaravola. Unpubl. report.

Combes, B. P. Y. 2005. The United Nations Decade of Education for Sustainable Development (2005-2014): Learning to live together sustainably. Applied Environmental Education \& Communication 4, 3 215-219. (doi:10.1080/15330150591004571)

Cotton, D. and Winter, J. 2010. It's not just bits of paper and light bulbs. A review of sustainability pedagogies and their potential for use in higher education. In: Sustainability Education: Perspectives and Practive Across Higher Education. P. Jones, D. Selby and S. Sterling (eds.), pp 39-54. Earthscan Ltd, London.

de Haan, G. 2006. The BLK '21' programme in Germany: a 'Gestaltungskompetenz'-based model for education for sustainable development. Environmental Education Research 12, 1: 19-32. (doi:10.1080/13504620500526362)

de Haan, G. 2010. The development of ESD-related competencies in supportive institutional frameworks. International Review of Education 56 , 2-3: 315-328. (doi:10.1007/s11159-010-9157-9)

De Laguna, G. A. 1960. The 'Lebenswelt' and the cultural world. The Journal of Philosophy 57, 25: 777-791. (doi:10.2307/2023376)

Dewey, J. 2004. Democracy and Education: An introduction to the philosophy of education. Dover Publications, Inc. Mineola, N.Y.

Dolins, F. L., Jolly, A., Rasamimanana, H., Ratsimbazafy, J., Feistner, A. T. C. and Ravoavy, F. 2010. Conservation education in Madagascar: three case studies in the biologically diverse island continent. American Journal of Primatology 72, 5: 391-406. (doi:10.1002/ajp.20779)

Etienne, M., Du Toit, D. R. and Pollard, S. 2011. ARDI: a co-construction method for participatory modeling in natural resources management. Ecology and Society 16, 1: 44. [online] <http://www.ecologyandsociety. org/vol16/iss1/art44/>
Evers, S. J. T. M. and Seagle, C. 2012. Stealing the sacred: Why 'global heritage' discourse is perceived as a frontal attack on local heritagemaking in Madagascar. Madagascar Conservation \& Development 7 , 2S: 97-106. (doi:10.4314/mcd.v7i2S.6)

Freire, P. 1970. Pedagogy of the Oppressed. The Continuum International Publishing Group Ltd, London.

Glick, P. and Sahn, D. E. 2006. The demand for primary schooling in Madagascar: Price, quality, and the choice between public and private providers. Journal of Development Economics 79, 1: 118-145. (doi:10.1016/j.jdeveco.2005.01.001)

Grantham-McGregor, S., Cheung, Y. B., Cueto, S., Glewwe, P., Richter, L. and Strupp, B. 2007. Developmental potential in the first 5 years for children in developing countries. The Lancet 369, 9555: 60-70. (doi:10.1016/S0140-6736(07)60032-4)

Hannah, L., Dave, R., Lowry II, P. P., Andelman, S., Andrianarisata, M., et al. 2008. Climate change adaptation for conservation in Madagascar. Biology Letters 4, 5: 590-594. (doi:10.1098/rsbl.2008.0270)

Hart, B. and Risely, T. R. 1995. Meaningful Differences in the Everyday Experiences of Young American Children. Paul H. Brookes, Baltimore, M.D.

Harvey, C. A., Komar, O., Chazdon, R., Ferguson, B. G., Finegan, B., et al 2008. Integrating agricultural landscape with biodiversity conservation in the Mesoamerican hotspot. Conservation Biology 22, 1: 8-15. (doi:10.1111/j.1523-1739.2007.00863.x)

Heberlein, T. A. 2012. Navigating Environmental Attitudes. Oxford University Press, Oxford.

Heneveld, W. and Craig, H. 1996. Schools Count: World Bank Project Designs and the Quality of Primary Education in Sub-Saharan Africa. World Bank, Washington, D.C. Available at <http://elibrary.worldbank.org/doi/ pdf/10.1596/0-8213-3460-3>

Heugh, K., 2000. The Case Against Bilingual and Multilingual Education in South Africa. PRAESA, Cape Town.

Horning, N. R. 2008. Strong support for weak performance: Donor competition in Madagascar. African Affairs 107, 428: 405-431. (doi:10.1093/ afraf/adn036

INSTAT (Institut National de la Statistique) 2012. <http://www.instat.mg/ index.php?option=com_content\&view $=$ article\&id=33\&ltemid $=>$ accessed 18 January 2014

IUCN 1980. World Conservation Strategy: Living Resource Conservation for Sustainable Development. IUCN, UNEP, WWF, Gland, Switzerland. Available at <https://portals.iucn.org/library/efiles/documents/WCS004.pdf>

Jacobson, S. K., McDuff, M. D. and Monroe, M. C. 2006. Conservation Education and Outreach Techniques. Oxford University Press, Oxford.

Jarosz, L. A. 1994. Taboo and time-work experience in Madagascar. Geographical Review 84, 4: 439-450. (doi:10.2307/215758)

Jensen, B. B. 2002. Knowledge, action and pro-environmental behaviour. Environmental Education Research 8, 3: 325-334. (doi:10.1080/13504620220145474)

Johnson, D. 2006. Comparing the trajectories of educational change and policy transfer in developing countries. Oxford Review of Education 32, 5: 679-696. (doi:10.1080/03054980600976411)

Keller, E. 2009. The danger of misunderstanding 'culture'. Madagascar Conservation \& Development 4, 2: 82-85. (doi:10.4314/mcd.v4i2.48647)

Kidd, A. H. and Kidd, R. M. 1989. Factors in adults' attitudes toward pets. Psychological Reports 65, 3: 903-910. (doi:10.2466/pr0.1989.65.3.903)

Kollmuss, A. and Agyeman, J. 2002. Mind the gap: Why do people act environmentally and what are the barriers to pro-environmental behavior? Environmental Education Research 8, 3: 239-260. (doi:10.1080/13504620220145401)

Lammers, P. L., Richter, T., Waeber, P. O. and Mantilla Contreras, J. In press. Lake Alaotra wetlands: ecological status quo in one of Madagascar's most important rice and fish production region. Madagascar Conservation \& Development.

Liimatainen, A. 2013. United Nations Decade of Education for Sustainable Development. In: Encyclopedia of Corporate Social Responsibility. S. O. Idowu, N. Capaldi, L. Zu and A. D. Gupta (eds.), pp 2606-2610. Springer Berlin, Heidelberg, Germany. 
Maminirina, C. P., Girod, P. and Waeber, P. O. 2006. Comic strips as environmental educative tools for the Alaotra region. Madagascar Conservation \& Development 1, 1: 11-14. (doi:10.4314/mcd.v111.44045)

MaxQDA software. <http://www.maxqda.com>

McDuff, M. and Jacobson, S. 2000. Impacts and future directions of youth conservation organizations: Wildlife clubs in Africa. Wildlife Society Bulletin 28, 2: 414-425.

Ormsby, A. 2008. Development of environmental education programs for protected areas in Madagascar, Applied Environmental Education \& Communication 6, 3-4: 223-232. (doi:10.1080/15330150801944515)

Palmer, J. A. 2003. Environmental Education in the $21^{\text {st }}$ century: Theory, Practice, Progress and Promise. Routledge London.

Paulhus, D. L. 1991. Measurement and control of response biases. In: Measures of Personality and Social Psychological Attitudes. J. P. Robinson, P. R. Shaver and L. S. Wrightsman (eds.), pp 17-59. Academic Press, San Diego.

Pavlova, M. 2011. Environmental Education and/or Education for Sustainable Development: What Role for Technology Education? Available at <http://www.gold.ac.uk/media/Patt\%20cript\%20conference\%20booklet\%20X-webversion-web.pdf\#page =333>

Pidgeon, M. 1996. An Ecological Survey of Lake Alaotra and Selected Wetlands of Central and Eastern Madagascar in Analyzing the Demise of Madagascar Pochard Aythya innotata. WWF/Missouri Botanical Garden, Antananarivo, Madagascar.

Rafidimanana Rajosera, M. 2013. Integration de la Bande Dessinée Arovy fa harena en tant qu'Outil Pédagogique au Niveau des E.P.P d'Ambatondrazaka et d'Amparafaravola. Unpubl. Master thesis. École Normale Supérieur, Antananarivo, Madagascar.

Raharijaona, R. L. J. \& Randrianarison, J. 1999. Facteurs géologiques et climatiques influençant l'érosion en lavaka et ensablement des rizières: le cas du massif d'Ambohitrandriampotsy du sud du Lac Alaotra. In: Actes du 4e Colloque International Organisé par l'Association pour les Montagnes Africaines (AMA). H. Hurni \& J. Ramamonjisoa (eds.), pp 159-172. Association pour les Montagnes Africaines, Antananarivo, Madagascar.

Rakotoarisoa, T. F., Waeber, P. O., Richter, T. and Mantilla Contreras, J. In press. Water hyacinth (Eichhornia crassipes), opportunity or threat for the Alaotra wetlands and livelihoods. Madagascar Conservation \& Development.

Randrianja, S. and Ellis, S. 2009. Madagascar: a short history. C. Hurst and Chicago University Press, London and Chicago.

Randrianja, S. 2012. Love me tender - transition vers où? Madagascar Conservation \& Development 7, 1: 9-16. (doi:10.4314/mcd.v7i1.3)

Rendigs, A., Reibelt, L. M., Ralainasolo, F. B., Ratsimbazafy, J. H. and Waeber, P. O. In press. Ten years into the marshes - Hapalemur alaotrensis conservation, one step forward and two steps back? Madagascar Conservation \& Development.

Renkl, A., Mandl, H. and Gruber, H. 1996. Inert knowledge: Analyses and remedies. Educational Psychologist 31, 2: 115-121. (doi:10.1207/ s15326985ep3102_3)

Rivkin, M. S. 1995. The Great Outdoors: Restoring Children's Right to Play Outside. National Association for the Education of Young Children, Washington, DC.

Robson, L. and Rakotozafy, F. In press. The freedom to choose: integrating community-based reproductive health services with locally-led marine conservation initiatives in southwest Madagascar. Madagascar Conservation \& Development.

Schultz, P. W. 2011. Conservation means behavior. Conservation Biology 25, 6: 1080-1083. (doi:10.1111/j.1523-1739.2011.01766.x)

Sharp, L. A. 2002. The Sacrificed Generation: Youth, History, and the Colonized Mind in Madagascar. University of California Press, Berkeley and Los Angeles.

Shepherd, A., Mitchell, T., Lewis, K., Lenhardt, A., Jones, L., et al. 2013. The Geography of Poverty, Disasters and Climate Extremes in 2030. ODI, London. Available at <http://www.odi.org/sites/odi.org.uk/files/odiassets/publications-opinion-files/8637.pdf>

Shonkoff, J. P. and Phillips, D. A. (eds.) 2000. From Neurons to Neighbourhoods: The Science of Early Childhood Development. National Academy Press, Washington, D.C.
Sobel, D. 1997. Sense of place education for the elementary years. In: Coming Home: Developing a Sense of Place in Our Communities and Schools. M. K. Baldwin (ed.), pp 32-39. Proceedings of the 1997 Forum, ERIC

Sunderlin, W. D., Angelsen, A., Belcher, B., Burgers, P. and Nasi, R. 2005 Livelihoods, forests, and conservation in developing countries: An overview. World Development 33, 9: 1383-1402. (doi:10.1016/j.worlddev.2004.10.004)

Tilbury, D. 1995. Environmental education for sustainability: defining the new focus of environmental education in the 1990s. Environmental Education Research 1, 2: 195-212 (doi:10.1080/1350462950010206)

Tilbury, D., Stevenson, R. B., Fien, J. and Schreuder, D. 2002. Education and Sustainability: Responding to the Global Challenge. IUCN Commission on Education and Communication. Available at <http://www.mma.gov. br/port/sdi/ea/deds/arqs/educandsust.pdf >

Tilbury. D. 2007. Learning based change for sustainability: perspectives and pathways. In: Social Learning Towards a Sustainble World. A. E. J. Wals (ed.), pp 117-132. Wageningen Academic Publishers, The Netherlands.

UNCED. 1992. Agenda 21, Promoting education and public awareness and training, chapter 36. United Nations Conference on Environment and Development, Conches.

UNDP. 2013. Human Development Report. The Rise of the South: Human Progress in a Diverse World. United Nations Development Programme. Available at <http://hdrstats.undp.org/images/explanations/MDG.pdf>

UNESCO. 1976. The Belgrade Charter. Connect: UNESCO-UNEP Environmental Education Newsletter 1, 1: 1-2.

UNESCO. 1978. The Tbilisi Conference. Connect: UNESCO-UNEP Environmental Education Newsletter 3, 1:1-8

UNESCO. 2013. Proposal for a Global Action Programme on Education for Sustainable Development as Follow-up to the United Nations Decade of Education for Sustainable Development (DESD) after 2014, Paris.

WCED. 1987. Our Common Future. United Nations World Commission on Environment and Development. Oxford University Press, Oxford.

Waeber, P. O. 2006. Roots \& Shoots: A model for active environmental protection. Madagascar Conservation \& Development 1, 1: 48-49. (doi:10.4314/mcd.v1i1.44121)

Wittkowski, J. 1994. Das Interview in der Psychologie. Interviewtechnik und Codierung von Interviewmaterial. Springer Fachmedien Wiesbaden $\mathrm{GmbH}$, Wiesbaden, Germany.

\section{SUPPLEMENTARY MATERIAL.}

AVAILABLE ONLINE ONLY.

FIGURE S1. Ranking environmental problems. Out of ten pictures, the interviewees were asked to choose and rank those that display potential environmental problems.

FIGURE S2. Interview guide for the structured in-depth interviews (in French) 